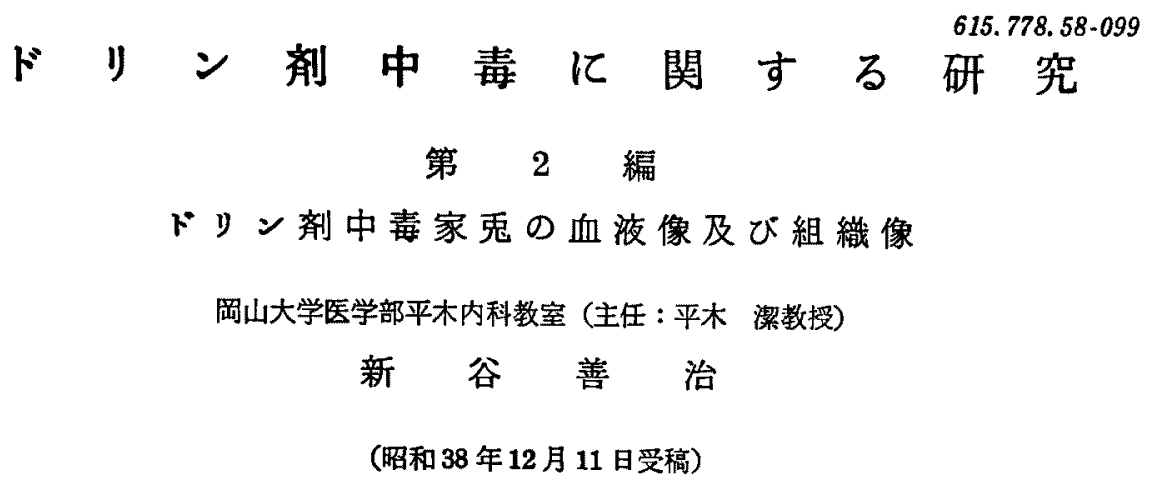

\section{I 楮 言 \\ II 実呀材料及び実験方法 \\ III 実銩成績}

（A） 急性中毒時血液像

（B）慢性中毒時血液像

\section{I 踷 言}

ドリン剂は一般に神経毒であり，実質毒であると 云われているか，致死作用の機序は尚不明であり， 生理作用についての研究も非常飞少い，血液倣対す 万作用化ついては 2，3 の症例報告に於いて白血 球数，白血球分類，赤血球数，血色素量等仁言及し ている程度の報告かみられるのみである。

他の有機塩素揢化於いては Friberg'28) は DDT. BHC 混合剂中毒死亡例を報告し，特に DDT は造 血滕器に強い媁害を及すと云い, 剖検所見を併世,

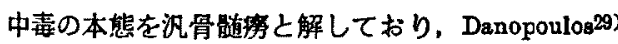
は $\gamma$-BEC 中毒で著明な貫血あり，骨䯣赤血球生成 機能障害と考えられる，と云つており，加納28)，

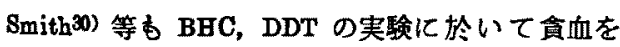
証めている。ドリン剂中毒時にも当然血液像倿変化 のある事か考えられ，本研究を行つた由縁である.

\section{II 実験材料及ひ実酫方法}

\section{(1) 実験動物}

体重 $2 \mathrm{~kg}$ 前後の雄性白色家冤を用いた。

\section{(2) 被験藤剂}

$\begin{array}{lll}\text { エンドリン } & 19.5 \% \text { 乳剂 } & \text { 三共農薬部製 } \\ \text { アルドリン } & 24.0 \% 6 \text { 乳剤 } & \text { 日本農薬製 } \\ \text { デイルトリン } & 18.5 \% \text { 乳剂 } & \text { 日本農薬製 }\end{array}$

(3) 実験方法

ドリン剂の皮下注射及び経口投与により，急性中

\section{容目次}

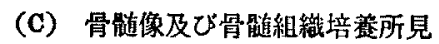

(D) 病理組織像

IV 考 按

$\mathrm{V}$ 結 語

毒，慢性中毒を起とさせた家兔の耳静脈より探血し $\tau$, 赤血球数, 血色㕝量, 白血球数, 白血球百分率 を測定し，Pappenheim 氏法に上り網状赤血球数を 算定した，更に一部に於いて骨㖪像を検し，教空考 按の骨髄組織培盖法34)により中毒時の骨艏機能を 検した. 又肝, 督, 肺, 脳, 脊能, 骨随を主に心, 小脳, 脾の病現組織像を Hematoxyline-Eosin 染色 法により検索した。

\section{III 実験成较}
（A）急性中毒時の血液像
（I）エンドリン急性中毒時血液像

半数致死量以上のエンドリン $20 \mathrm{mg} / \mathrm{kg}, 30 \mathrm{mg}$ /kg を各 4 例, 何れ皮下注射に上り急性中素を起 させた家鬼について血液像を検した. エンドリン50 $\mathrm{mg} / \mathrm{kg}$ 皮下注射の 1 例は白血球数及び白血球百分 率のみを険した。

（i）赤血球数，血色量及び种状赤血球数 赤血球数, 血色素量とも中毒の初期に極〈怪度の 増加を示したものが多く，大部分は24時間以内に死 亡した．数日間以上生存した例では対照に比し明ら かな変化を示さず，著明な貫血を来たしたものもな かつた.

(ii）白血球数及び白血球百分率

急性中毒の初期には白血球增多を示す6のが多く， 特に激しい廰笔を来たした例では白血球数が増加す る傾向を示した．白血球百分率では傮好酸球の增加， 
第 1 図エンドリン急性中毒家鬼血液像

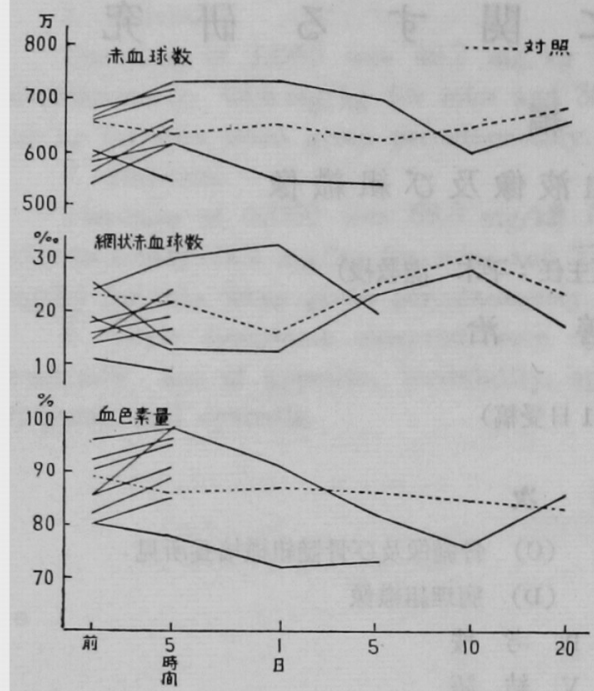

第 2 図エンドリン急性中毒家鬼白血球数

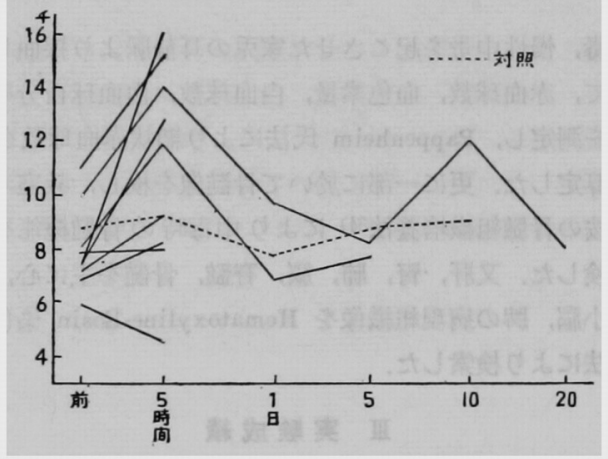

リンパ球の減少があり,・好酸球は減少乃至は消失し， 24時間以内に死亡するすのが多かつた. 百分率のう ち單球, 好酸球, 好塩基球については平均值で示し た.

जी 1

*⿻一𠃋十

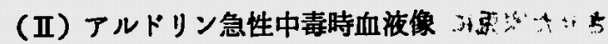
半数致死置以上のアルドリンを次の如く皮下注射 し，急性中毒を起させた家鬼について血派像を検し た。即ち $60 \mathrm{mg} / \mathrm{kg} 1$ 例, $90 \mathrm{mg} / \mathrm{kg} 3$ 例, $120 \mathrm{mg}$ $/ \mathrm{kg} 1$ 例である. 尚 $250 \mathrm{mg} / \mathrm{kg}$ の 1 例は白血球数

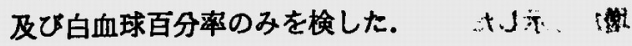

（i）赤血球数，血色素量及び網状赤血球数！.」 第 4 図に示す如 く，赤血球数，血色素击及び網状

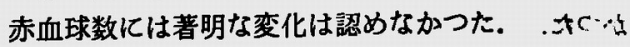

(ii) 白血球数及び白血球百分率

，第 5 図の如く著明な白血球增加を示したすのと， 減少を示したものとがあり，必ずしも一定の傾向を 示さなかつた。
第3図エンドリン急性中毒家鬼白血球百分率
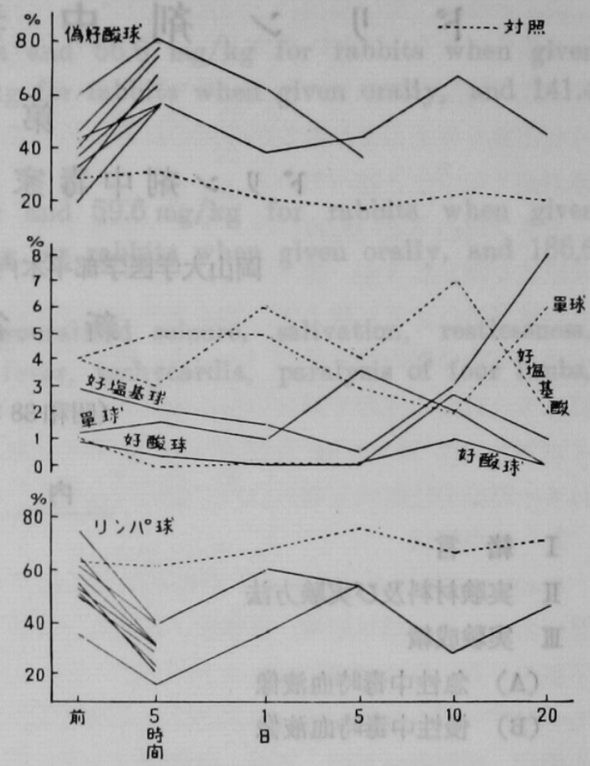

第4四アルトリン急性中毒家鬼血液像

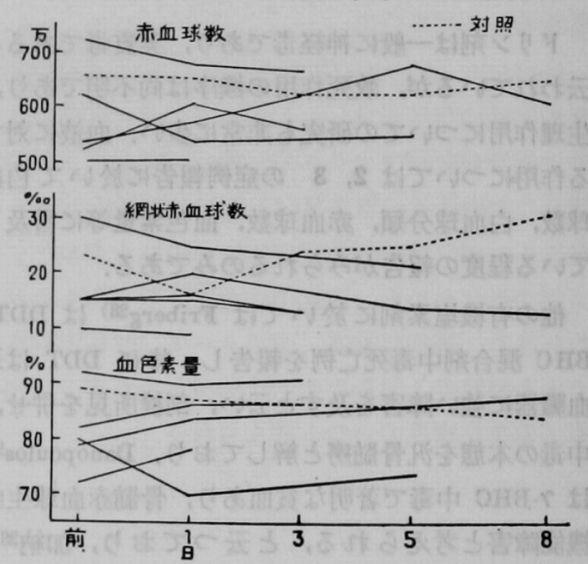

第 5 図アルドリン急性中毒家鬼白血球数

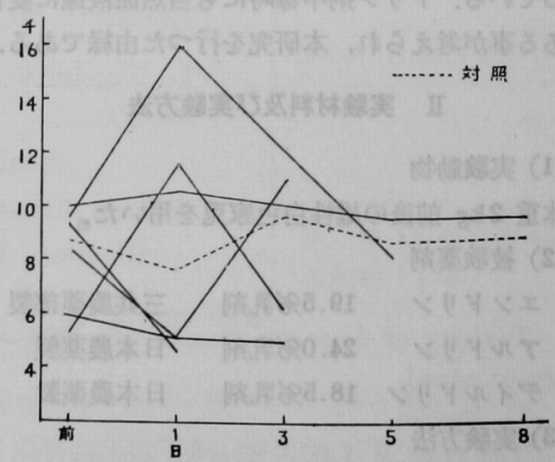


第6因フルトリキ急性中毒家鬼白血球百分率
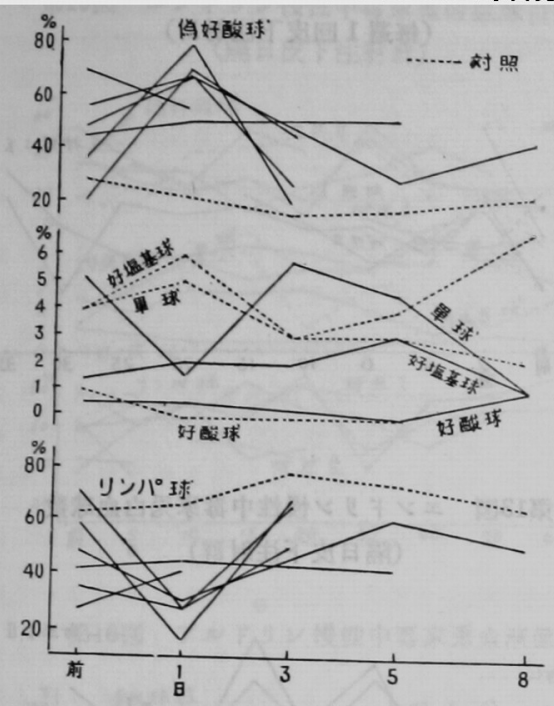

白血球百分率では中毒の初期に偽好酸球の増加, リンパ球の㳀少を示すすのが多かつた。

（III）ティルドリン急性中毒時血液像

半数致死量以上のデイルドリンを次の如く皮下注 射し，急性中毒を起させた家兔について血液像を検 した. 即 $550 \mathrm{mg} / \mathrm{kg} 1$ 例, $70 \mathrm{mg} / \mathrm{kg} 3$ 例, 90 $\mathrm{mg} / \mathrm{kg} 2$ 例で $120 \mathrm{mg} / \mathrm{kg}$ の 1 例は白血球数及び白 血球百分率のみを検した。

（i）赤血球数，血色素量及び網状赤血球数 第 7 四に示した如く，赤血球数，血色素量，網状 赤血球数には著明な变化は認められなかつた。

(ii）白血球数及び白血球百分率

白血球数は中毒の初期に增加を示し減少するすの， 浅少後増加するもの，又減少を示すものああり必ず しも一定の煩向を示さなかつた. 死亡前氫擎を来た した2 例は白血球の堌加を示さなかつた。

白血球百分率では偽好酸球増加、リンパ球减少を 示すものか多かつた。

（B）慢性中毒時の血液像 -

（1）エンドリン慢性中毒時血液像

半数死量以下のエンドリンを次の如く皮下注射 し血液像を検した，即与每週 1 回皮下注射群は $5 \mathrm{mg}$ $/ \mathrm{kg}$ 週 1 回 3 例; $10 \mathrm{mg} / \mathrm{kg}$ 週 1 回か 2 例で 7 日毎 飞探血し，隔日皮下注射群は $4 \mathrm{mg} / \mathrm{kg} 3$ 例， $9 \mathrm{mg}$ /kg 3例で 5 日毎に採血した。図に示した対照Iは 正常家鬼にドリン剂乳剂の主成分であるキシレンを $0.2 c c$ 宛隔日に皮下注射後採血して検した 2 例の平 均值である。
第 7 図 ディルドリン急性中毒家鬼血液像

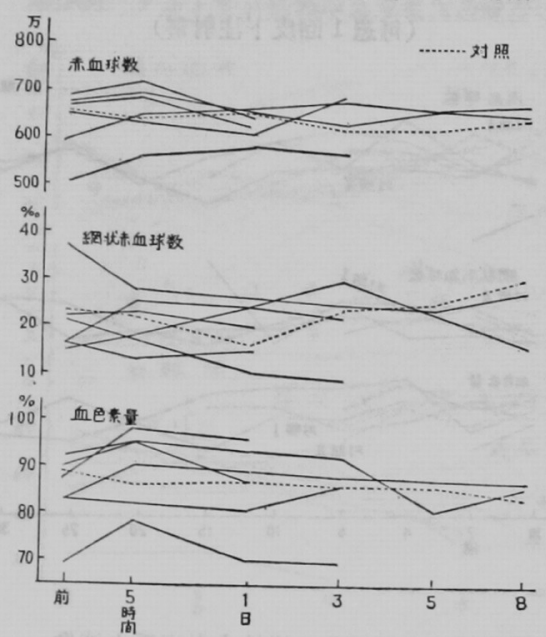

第 8 図 ディルドリン急性中毒家鬼白血球数

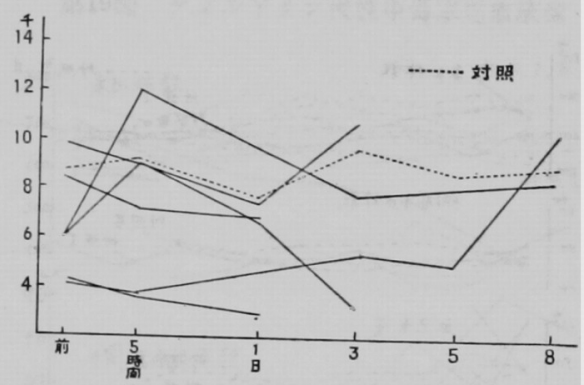

第 9 図 ディルドリン急性中毒家鬼白血球百分苑
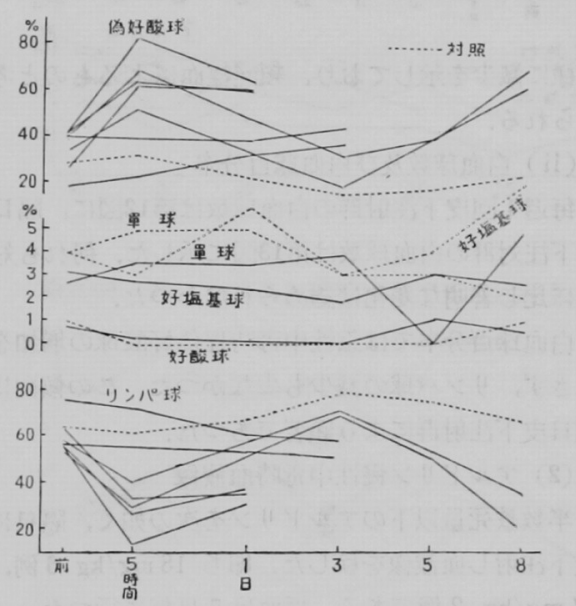

（i ）赤血球数，血色意量及び網状赤血球数 毎週 1 回皮下注射群は第10図に，隔日皮下注射群 は第11図に示した。隔日皮下注射群の赤血球数，血 色甞量が渐次隇少の傾向を示しているが対照も略ヶ 
第10図 エンドリン慢性中毒家鬼血湾像

（每䓢 1 回皮下注射群）

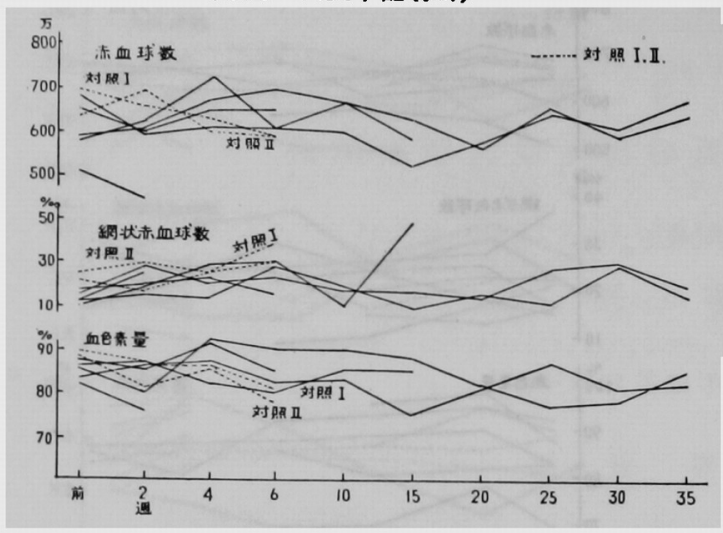

第11図エンドリン慢性中毒家鬼血液像 （隔日皮下注射群）

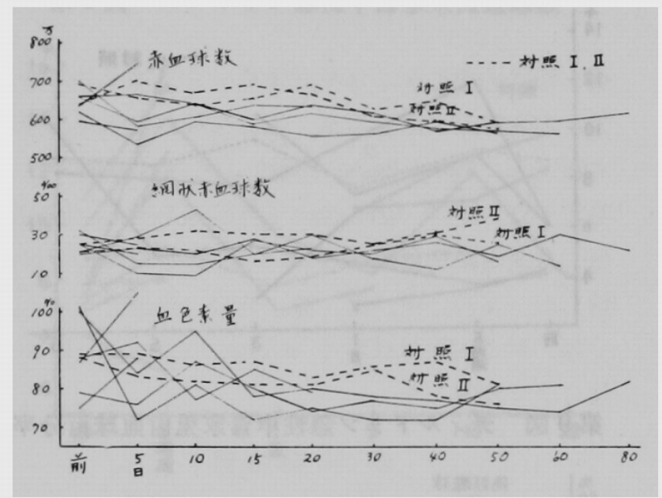

同様に減少を示しており，頼回探血によるあのと考 えられる。

(ii）白血球数及び白血球百分率 毎週 1 回皮下注射群の白血球数は第12図に，隔日 皮下注対群の白血球数は第13図に示した，何れも対 照に比し著明な変化は認められなかつた。

白血球百分率では急性中毒時程偽好酸球の増加を 示さず,リンパ球の減少も少なかつた，ての傾向は 隔日皮下注射群により䫓著であつた。

（2）アルドリン慢性中毒時血液像

半数致死量以下のアルドリンを次の如く，隔日に 皮下注射し血液像を検した. 即ち $18 \mathrm{mg} / \mathrm{kg} 6$ 例， $37 \mathrm{mg} / \mathrm{kg} 2$ 例である. 採血は 5 日毎に行つた.

(i ) 赤血球数, 血色素量及び網状赤血球数

第16図の如く，特に血色素加軽度に漸次減少する 傾向を示したが対照 I，IIも略々同様であつた．網 状赤血球は㹩度に渐次增加を示した。
第12図 エンドリン惯性中毒家鬼白血球数 （毎遇 1 回皮下注射群）

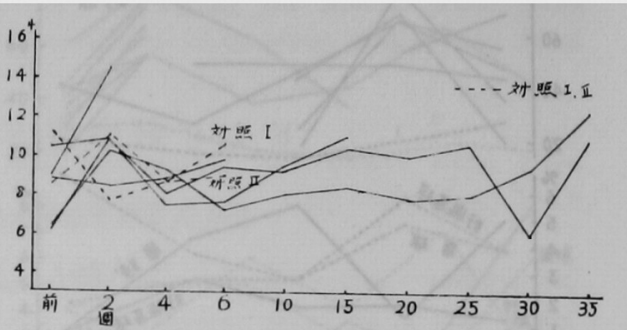

第13図 エンドリン慢性中毒家克白血球数 （隔日皮下注射群）

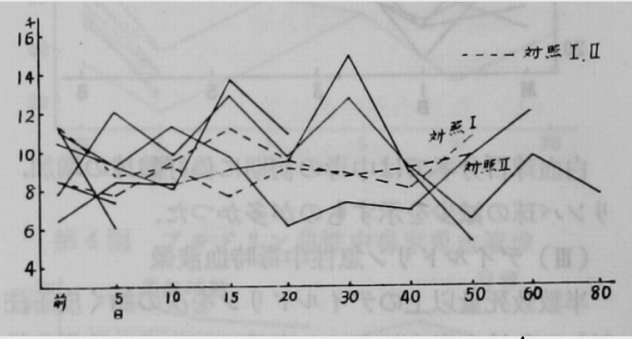

第14図エンドリン慢性中毒家鬼白血球百分率 （毎週 1 回皮下注射群）

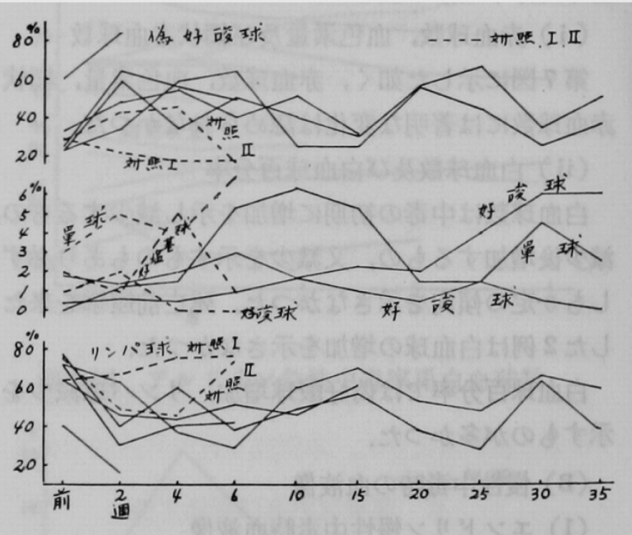

(ii) 白血球数及び白血球百分率

第17図の如く白血球数は増減区々で一定の傾向は 示さなかつた.

白血球百分率は第18因に示した．約 2 週間後より 漸次偽好酸球が増加し、リンパ球が減少した。

（3）デイルドリン慢性中毒時血液像

半数致死量以下のディルドリンを次の如く隔日に 皮下注射し，5 日毎倸血して血液像を检した。即 
第15四 エンドリン愠性中繁家鬼白血球百分率 (隔日皮下注射群)

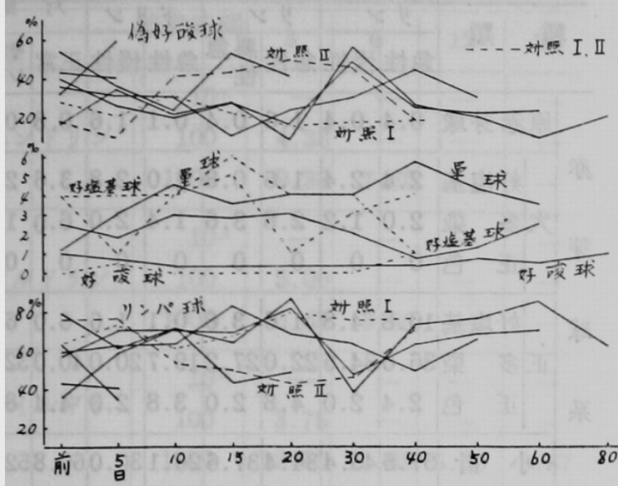

第16図 アルドリン慢性中毒家鬼血液像

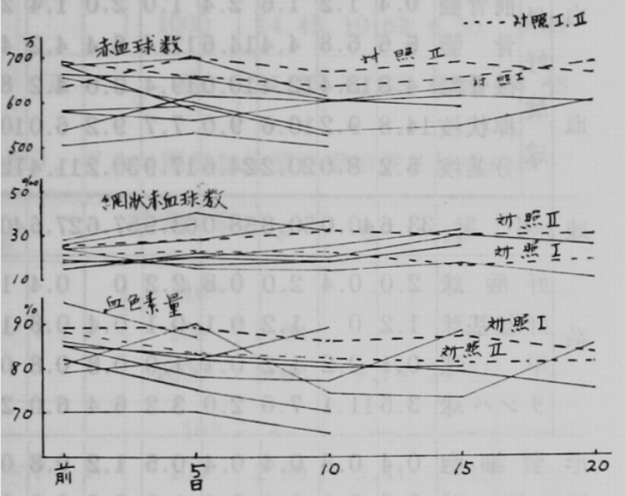

第17図 アルドリン慢性中毒家鬼白血球数

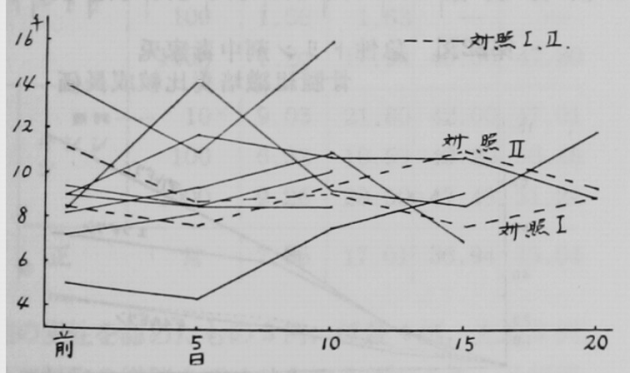

$518 \mathrm{mg} / \mathrm{kg} 6$ 例, $36 . \mathrm{mg} / \mathrm{kg} 2$ 例である.

（i ）赤血球数，血色素及び網状赤血球数

第19図の如く赤血球数，血色素量は濑次隇少する 傾向を示したが対照も同様であつた，うち 1 例が䨘 血を来たしたが中毒症状は何等認めなかつた。

(ii) 白血球数及び白血球百分率 白血球数には著明な変化はなかつた。

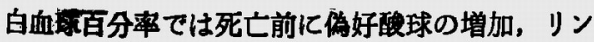

第18図 アルドリン慢性中毒家鬼白血球百分率

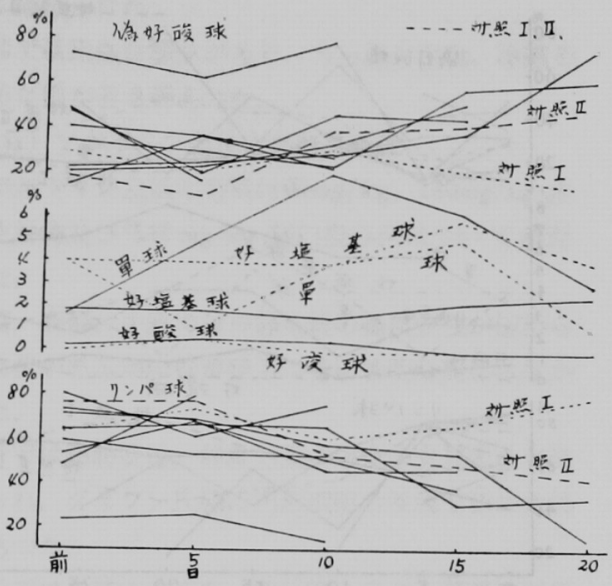

第19図 ディルドリン慢性中毒家鬼血液像

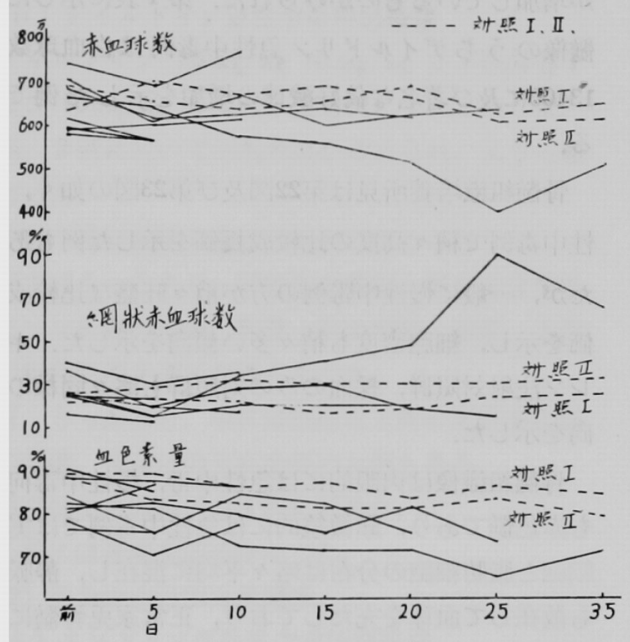

第20図 ディルドリン慢性中毒家鬼白血球数

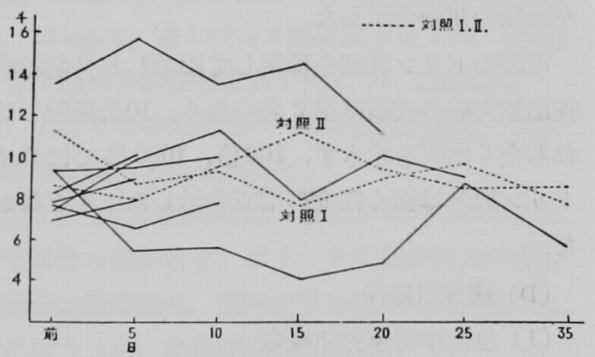

パ球減少の傾向がみられた。

(C) 骨䯇像及び骨䯙組織培食所見

ドリン剂中毒家兔骨娟道像は急性中毒, 慢性中毒と 
第21図 ディルトリン慢性中毒家鬼白血球百分率

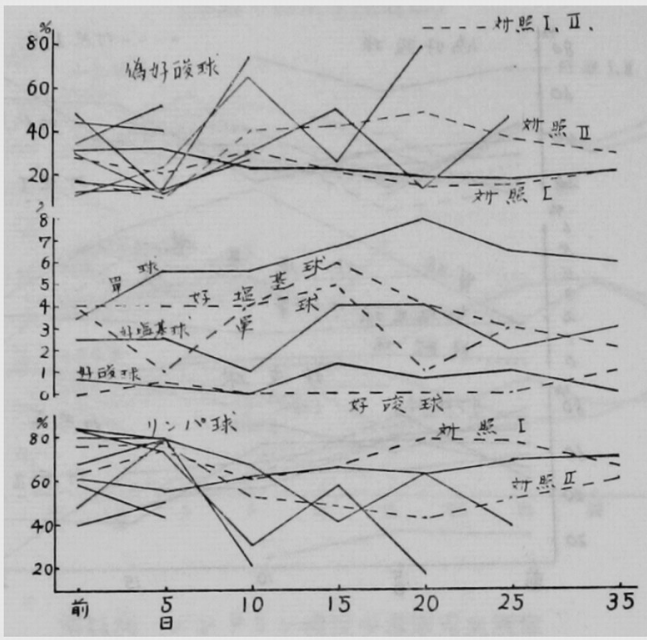

6白血球数の増加例に於いて白血球系細胞の百分率 が増加しているものがみられた。第 1 表に示した骨 髄像のうちデイルドリン急性中毒例は白血球数が 13400に及び著名な偽好酸球の堌加を示した例であ 3.

骨䯣組織培侅所見は第22図及び第23図の如く，急 性中琵例で稍々高度の比較成長価を示した例もあつ たが，一般に慢性中毒例の方が稍々旺盛な比較成長 価を示し，細胞密度も稍々多い傾向を示した．キシ レン注射対照群，採血のみの対照群も略々同様の傾 向を示した。

骨髄組織像は肉眼的には急性中毒, 慢性中毒何れ あ赤色髄であり，顕微鏡的には急性中毒例では実質

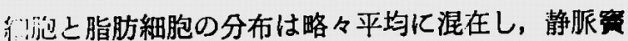
も散在して血球を充たしており，正常家鬼骨髄に比 し著変は認めなかつた，慢性中毒例のうちに実質細 胞の増殖した傾向を示すすのが見られたが対照も略 々同様の傾向を示した。

市販のドリン乳剂を稀釈して添加した骨髄組織培 益添加実験の成績は第 2 表の如く，10倍稀釈では何 れも全く増成を示さず, 100 倍, 1000 倍ではデイル ドリン以外は極く軽度の増成を示したにすぎなかつ た.

(D) 病理組織像

（1）急性中毒家鬼組織像

（i）エンドリン急性中䇘時組織像

エンドリン $10 \mathrm{mg} / \mathrm{kg}$ 皮下注射 1 例, $20 \mathrm{mg} / \mathrm{kg}$ 5 例 $30 \mathrm{mg} / \mathrm{kg} 3$ 例について検討した. 脳では神経
表 1、ドリン刘中毒家鬼骨㴹像

\begin{tabular}{l}
\hline 種類 \\
\hline
\end{tabular}

第22因 急性ドリン郕中毒家鬼 骨鲢組織培養比較成辰価

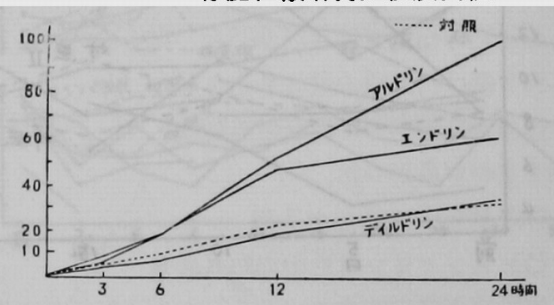

第23図慢性トリン剂中毒家鬼 骨䇱組織培養比較成長価

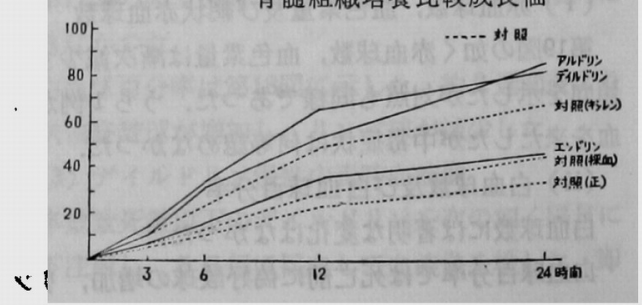




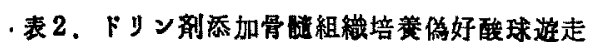
速度 $(\mu / \mathrm{m})$

\begin{tabular}{|c|c|c|c|c|c|c|}
\hline \multicolumn{2}{|c|}{ 種類 } & 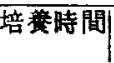 & 3 & 6 & 12 & 24 \\
\hline \multirow{3}{*}{\multicolumn{2}{|c|}{ エンドリン }} & $10 \times$ & - & - & - & - \\
\hline & & 100 & 4.38 & - & - & - \\
\hline & & 1000 & 9.38 & 7.50 & - & - \\
\hline \multirow{3}{*}{\multicolumn{2}{|c|}{ アルトリン }} & $10^{x}$ & - & - & - & - \\
\hline & & 100 & 5.00 & - & - & - \\
\hline & & 1000 & 3.63 & 3.50 & - & - \\
\hline \multirow{2}{*}{\multicolumn{2}{|c|}{$\begin{array}{l}\text { ティルドリ } \\
\text { У }\end{array}$}} & $10^{x}$ & - & - & - & - \\
\hline & & 100 & 3.75 & - & - & - \\
\hline \multirow[t]{3}{*}{ 対 } & & $10^{x}$ & 10.62 & 8.75 & 6.63 & 5.43 \\
\hline & $\neq 00$ & 100 & 20.63 & 10.63 & 3.90 & 4.10 \\
\hline & & 1000 & 14.43 & 10.63 & 6.50 & 3.82 \\
\hline 照 & 正 & 常 & 11.25 & 10.65 & 6.32 & 4.68 \\
\hline
\end{tabular}

凑 3，ドリン郕添加骨艏組織培美比較成長価

\begin{tabular}{|c|c|c|c|c|c|c|}
\hline \multicolumn{2}{|l|}{ 喠類 } & 培萬時間| & 3 & 6 & 12 & 23 \\
\hline \multirow{3}{*}{\multicolumn{2}{|c|}{ エンドリン }} & $10^{x}$ & - & - & - & - \\
\hline & & 100 & 3.34 & - & -1 & 一 \\
\hline & & 1000 & 5.33 & 9.79 & 24.31 & - \\
\hline \multirow{3}{*}{\multicolumn{2}{|c|}{ アルドンン }} & $10^{x}$ & - & - & 一 & - \\
\hline & & 100 & 2.59 & 3.41 & 5.15 & - \\
\hline & & 1000 & 3.36 & 3.57 & - & - \\
\hline \multirow{2}{*}{\multicolumn{2}{|c|}{$\begin{array}{l}\text { デイルドリ } \\
y\end{array}$}} & $10^{\times}$ & - & - & - & - \\
\hline & & 100 & 1.56 & 1.63 & - & - \\
\hline \multirow{4}{*}{ 対 } & & & & & & \\
\hline & & $10^{x}$ & 9.03 & 21.80 & 42.00 & 47.01 \\
\hline & $\begin{array}{l}\text { キンV } \\
\text { ン }\end{array}$ & 100 & 6.33 & 19.59 & 49.20 & 58.46 \\
\hline & & 1000 & 9.26 & 23.50 & 47.43 & 51.24 \\
\hline 照 & 正 & 常 & 7.86 & 17.01 & 36.94 & 45.04 \\
\hline
\end{tabular}

緗胞の変性を認めたもの 3 例, 浮腫 4 例, 克血 2 例, グリア細胞の増殖を認めたもの 1 例があり，又何等 変化を認めないものもあつた。

春噵では神経細胞の変性を認めたもの6 例, 壊死 を琶めたものか 2 例あつた。

小脳ではプルキンエ細胞の一部に変性を認めたす の1例，グリア細胞の增殖を䜑めたものが1例あつ た.

肝化はうっ血, 出血加認められ，著明な変性，殊 飞空泡変性を証めたものが 2 例あつた。
腎では出血性腎炎が認められ，うっ血が著明で 6 例に認められた。

肺でば出血性肺炎があり，うっ血, 出血, 浮腫を 諗めた例が各 3 例あつた。

（ii）アルドリン急性中毒時組織像

アルドリン急性中毒例は $90 \mathrm{mg} / \mathrm{kg}, 150 \mathrm{mg} / \mathrm{kg}$ 皮 下注射例及び $110 \mathrm{mg} / \mathrm{kg}$ 経口投与例について検討 した.

脳, 脊䯣, 小脳では神経線維の軽度变性が認めら れた例があるが中枢神経系に特に著明な変化はなか つた.

肝では脂肪変性, 軽度乃至中等度の実質变性が認 められグリンン氏鞘に円形細胞の浸澗を認めた例 があつた。

腎では糸球体の充血，細尿管上皮の実質变性が認 められた。

肺ではうっ血あり，著明な肺炎は認めなかつた。

(ii）デイルドリン急性中毒時組織像

デイルドリン $50 \mathrm{mg} / \mathrm{kg} 70 \mathrm{mg} / \mathrm{kg}$ 皮下注射各 1 例及び $50 \mathrm{mg} / \mathrm{kg} 2$ 回皮下注射例について検した。

媨，2例に於いて空泡形成加認めら机，又うっ血 を認めた。

脊噵，神経細胞の変狌が 2 例に認められた。

肝ではうっ血あり，肝細胞の萎縮，軽度実犋変性， グリソン氏鞘の增殖，胆管上皮の增殖，剝脱，上皮 下の細胞浸潤認めた例もあつた。

腎，うっ血あり，中には細尿管上皮の実質变性䫻道 軼の萎縮，系球体の充血を認めた例もある。

肺では出血性肺炎を 1 例に認めた。

心筋には著变を認めなかつた。

（2）亜急性中毒家兔組緇像

(i) エンドリン亜急性中毒時組織像

エンドリン $10 \mathrm{mg} / \mathrm{kg}, 20 \mathrm{mg} / \mathrm{kg}, 30 \mathrm{mg} / \mathrm{kg}$ 之每 週 1 回 $10 \mathrm{mg} / \mathrm{kg}$ 宛濑增皮下注射し死亡せる家兔 1 例, $10 \mathrm{mg} / \mathrm{kg}$ 週 1 回宛 3 回注射家鬼 1 例, $20 \mathrm{mg}$ /kg 週 1 回腕 2 回注射家鬼 1 例について検した。

脳，小脳では神経細胞の一部䎲変性があり，又円 形細胞の浸润，充血を認めた。

脊喣では神経細胞の変性，壊死が 2 例汇みられた。 所ではうっ血があり，デイッセ氏腔の搪大が著明 で肝細胞の脂肪变性，空胞変性を認めた例があつた。 留にはうっ血，出血が認められた。

（ii）アルドリン亚急性中毒時組織像

アルドリン $25 \mathrm{mg} / \mathrm{kg}, 50 \mathrm{mg} / \mathrm{kg}$ と每週 1 回宛 2 回皮下注射後死亡せる家寃 1 例, $25 \mathrm{mg} / \mathrm{kg}$, 毎週 1 
回宛 2 回皮下注射家鬼 1 例， $50 \mathrm{mg} / \mathrm{kg}$ 婉每週 1 回 合計 5 回皮下注射せる家鬼 1 例について検した。

脳、脊榷では神経細胞の変性を認めた例があり， 又何等変化を認めないあのもあつた。

肝ではうっ血があり，出血や肝細胞の能助変性を 認めるものがあり，グリソン氏刺に於りる円形細胞

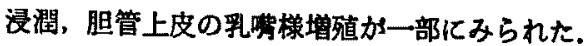

筩，著変を認めなかつた。

肺，うっ血あり，出血性肺炎の像を呈し，一部に 肺胞壁の増殖肥厚あり.

心では一列に於いて心筋の変性が認められた。

（iii）デイルドリン亜急性中毒時組維像

ブイルドリン $25 \mathrm{mg} / \mathrm{kg}$ 每週 1 回宛 4 回皮下注射 家鬼 1 例及び $50 \mathrm{mg} / \mathrm{kg}$ 每週 1 回宛 3 回皮下注射家 鬼 1 例飞ついて検した。

脸，脊䯙では軽度のうっ血があり，一部に於いて 神経細胞の変性を認めた。

小脳には著明な变化は認められなかつた。

肝にはうっ血があり，一部肝緇胞の変性を認めた。

䀞ではうっ血あり，一部系球体の充血を認めた。

肺では出血性肺炎の像がみられた。

（3）慢性中毒家鬼組䋐像

（i）エンドリン慢性中毒時組織像

エンドリン $10 \mathrm{mg} / \mathrm{kg}$ 每週 1 回宛16回及び34回皮 下注射家兔 2 例及び $5 \mathrm{mg} / \mathrm{kg}$ 每週 1 回宛34回皮下 注射せる家鬼 1 例について検した。

脳，脊髄では著明な変化は認めなかつたが，うっ 血、グリア細胞の軽度增殖を一部に認めた例がう た.

肝にはうっ血があり，実䖝の柽度脂肪変性，胆管 上皮の增殖を認めた例もあつた。

周では系球体の充血があり，系球体腎资の像を呈 し，又細尿管上皮の実質変性を認めた例がある.

肺, うっ血あり, 一部動脈壁の肥厚变性加認めら れた。

脾、著変は認めなかつたが，一部にうっ血，小動 眽壁の肥厚がみられた。

(ii）アルドリン慢性中毒時組織像

アルドリン $10 \mathrm{mg} / \mathrm{kg}$ を隔日に11回皮下注射せる 家鬼 1 例， $18 \mathrm{mg} / \mathrm{kg}$ 隔日 7 回及び 8 回皮下注射せ 万家鬼各 1 例及び $25 \mathrm{mg} / \mathrm{kg}$ 每週 1 回宛30回皮下注 射せる家鬼 1 例について検討した。

脳には著変を認めなかつた。

脊遏では前角細胞の萎縮を認めた。

旰，グリソン氏鞘の軽度円形細胞浸洞，柽度実質
変性を認めた例があつた。

堅では軽度充血，うっ血，細尿管上皮の実質変性 等がみられた。

肺。うっ血, 出血があり, 肺炎像を認め, 又軽度 限局性間質性肺炎を示した例もあり，肺炎を認めな い例もあつた。

心族には萎縮，充血を認めたるのがあつた。

(iii) デイルドリン慢性中毒時組織像

デイルドリン $10 \mathrm{mg} / \mathrm{kg}$ 隔日18回皮下注射家鬼 1 例, $18 \mathrm{mg} / \mathrm{kg}$ 隔日 12回及び23回皮下注射家鬼各 1 例, $25 \mathrm{mg} / \mathrm{kg}$ 毎週 1 回宛 8 回皮下注射家鬼 1 例飞 ついて検した。

脳では出血，グリア細胞の増殖，結節形成，神経 細胞の軽度変性等が認められた。

脊䯣で住神経細胞の变性，填死，萎縮等がみられ た.

肝ではうっ血が高度に認められ，慢性の脂肪変性 が認められた。

等，系球体に古血，出血あり，細尿管上皮の実質 変性が高度に認められた例があつた。

肺, 浮腫, うっ血, 出血がみられ, 出血性肺炎の 像を呈し，又肺胞壁の肥厚を認めた。

\section{IV 考按}

ドリン剂中毒時の血夜像のうち赤血球数，血色甞 量, 網状赤血球数等の赤血球系には著明な変化は みられず，Friberg23) ゃ Danopoulo828)，加納26)， Smith ${ }^{30)}$ 等が DDT や BHC 等の他の有機塩素都 中毒時に報告している様な会血を来たした例は認め なかつた。

白血球系では他の毒物中毒の際と略々同様て，白 血球数の軽度増加，好中球百分率の増加，好酸球減 少の傾向を認めた。

福原6)，Spiotta 13)，Nelson19) 等も白血球数の增加 を報告している．然しながら中毒の程度と白血球数 の增加は必ずしあ平行して起らず，死亡前でる増加 のみられないものもあり，中毒の程度を血波像より うかか心い知る事は出来ない，他の中毒時に出現する と云われる好中球の中毒顆柆は塗り認めなかつた。

骨䯣像，骨骵組織培所見，網状赤血球の動向等 よりみても骨髄機能は良好飞保持されておりててれ 等の点よりみてすドリン剂中毒時の血湤系に対する 作用は二次的のすのと考えられる.

病理組維的には急性中毒，慢性中毒とも変化は略 々同棣で，容易に中毒死飞至らず長期間生存した慢 
生中毒例では变化か軽度であつた。

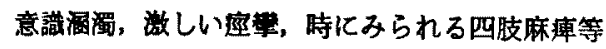
の中枢神経障害はドリン剂中毒時の最ち重要な病像 であろが，中枢柛释系の病理組樴所見については Dutre13) 等はアルドリン中毒の為死亡した動物で広 籍なうっ血, 節細胞の变性, Neuronophagia を認め ているか，他方 Conley14) 福原6) 等は病理組蟣的に 中枢神経系には決定的な变化は認めなかつたと述へ ている. 著者の実験では脳，脊哃造の神経細胞の変性 を証めたものが稍々多く，一部䧇死を認めたすの， グリア結簛を認めたもの等があるが，殆んど変化を 証めなかつたすのもあり，全例に必ず認められるよ なう組織変化はなかつた，又動物実験に於いて意識 泪斶、喘鳴、チアノーゼを伴う激しい氫攀の為死亡 直前にある如き家鬼でる，ネンブタールの如き強力

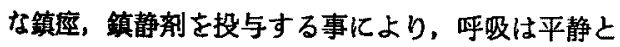
なり，数命し得ない迄す死亡迄の時間を大巾に延長 する事が出来る，等の点よりみても本剂中毒時仙 組栱的に決定的な変化を大脳に来たするのではなく， 中枢神経系の醉素化学的又は生化学的な変化の為䎲 的重大な中枢神経の機能異常が惹起されるので はないかと考えられる，他方ドリン剂は神経毒であ ると同時に実質毒であると云われ Conley 14) 福原の，

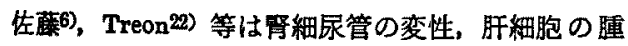
張，変性，肺浮連，心内膜炎等を認めているが， Conléy 14)，佐藤6) 等は他の有機塩素剂同様非特異的 な変化であると云つている，著者の実呀でも肝，留， 肺等に变化を認めているが実貢埛器に於仃る最す特 微的な所見はうっ血が著明な事であつた，臟器別に 所見を総括すると次の如くである. 肝では特に中心 部うっ血が著明で肝細胞の変性を認めた。堅ではう っ血が殆んど全例に認められ，一部系球体の克血，
出血があり，出血性系球体腎炎の像を認めた．肺で は多数例に出血性肺炎を認めた．以上の如く実質膕 器にかなり著明な変化がみられる点はドリン剂中毒 の治療の際特汇考魔を要するすの上思われる。

\section{$\mathrm{V}$ 結 語}

著者は家鬼について急性, 亜急性及ひ慢性ドリン 剂中毒を惹起せしぬ，その血液像，骨髄像，病理組 識的変化を検し次の結果を得た。

1. 急性中毒, 慢性中毒とも赤血球数，血色素量， 網状赤血球数等の赤血球系には対照に比し著明な变 化は認められなかつた。

2. 白血球系では急性中毒時, 特にエンドリン急 性中毒時们白血球数の增加，偽好酸球百分率の増加， リンパ球百分率の減少並に好酸球娍少の傾向を認め た。僈性中毒時には著明な变化はなかつた。

3. 骨骵機能は急性中毒時慢性中毒時何九殆ん ど障害されなかつた。

4. 病理組織像仔急性中毒, 慢性中毒とも略々同 様で脳, 脊能では神経細胞の変性があり又壊死, 浮 腫, 充血、グリア細胞の增殖等もみられた。肝では うっ血, 肝細胞の変性か，堅では出血性系球体堅炎 及び尿細管上皮の変性が，肺では出血性肺炎があり 又浮厘を認めた。

擱筆するに当り終始御指導と御校閲を睗つた恩師 平木教授並に武田講師に深甚なる謝意を表す。

組織標本所見について御高教を媔いた本学病理学 教室小田助教授，木本講師に深謝す。

（本諭文の要旨は符35回産業医学会総会に於いて 発表した.) 


\title{
Studies on Drin Intoxication
}

\section{Hematological and Histological Studies of Rabbits Intoxicated with Drins}

\author{
Yoshiharu Niiya \\ Department of Internal Medicine, Okayama Univeraity Medical School
}

(Director: Prof. Kiyoshi Hiraki)

The author iuduced acute, subacute, or chronic drin intoxication in rabbits and studied their peripheral blood pictures, myelograms, and histological changes. The results obtained are as follows.

1. Erythropoietic activities as reflected by red cell counts, hemoglobin, and reticulocyte counts were not significantly altered in comparison to controls by acute or chronic intoxication of drins.

2. In acute intoxication, particularly of endrin, there were leukocytosis and pseudoeosinophilia with relative lymphopenia and eosinopenia. Chronic drin intoxication caused no significant changes in the white blood cell series.

3. Hematopoietic activities of the bone marrow were hardly damaged in either acute or chronic intoxication of drins.

4. Histological changes induced by drins were almost identical in acute and chronic intoxication. The brain and spinal cord showed degeneration and necrosis of the ganglion cells, edema, congestion, and proliferation of the glia cells. In the liver there were congestion and degeneration of the liver cells. The kidneys revealed hemorrhagic glomerulonephritis and degeneration of tubular epithelium. The lungs also showed edema and hemorrhagic pneumonitis. 


\section{新谷䜽文附図}

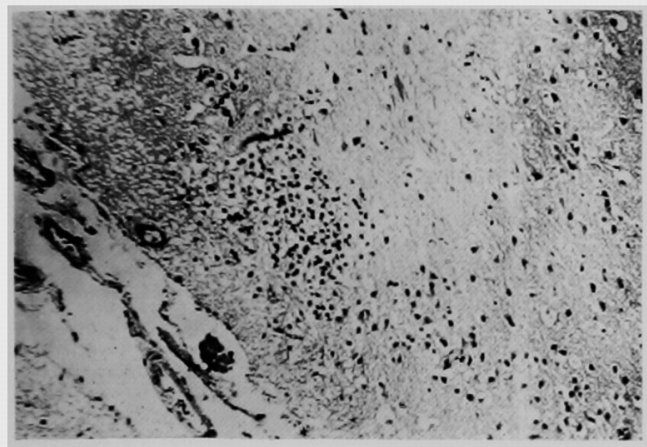

エンドリン $30 \mathrm{mg} / \mathrm{kg}$ 皮下注射家鬼, 脸,

クリア紐胞增殖しグリア結節を形成している.

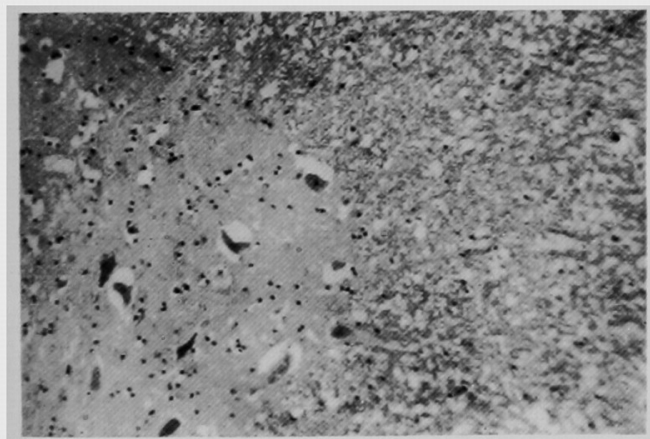

同上家鬼，

背檤前角領域の神経細胞の変性ちり。

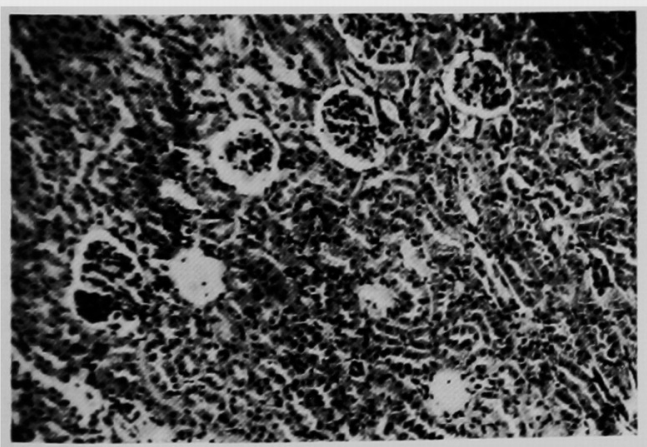

エンドリン $10 \mathrm{mg} / \mathrm{kg}$ 皮下注射家兔，

出血性系球体堅炎及び細尿管上皮の变性がみら

れる。

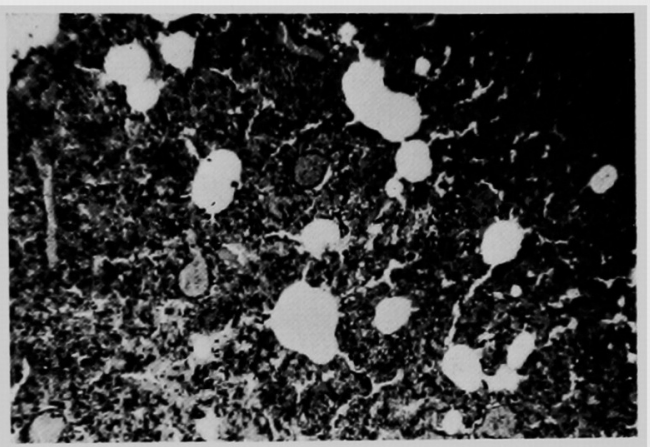

ディルドリン $50 \mathrm{mg} / \mathrm{kg} 2$ 回皮下注射家鬼.

出血性肺炎を示している。

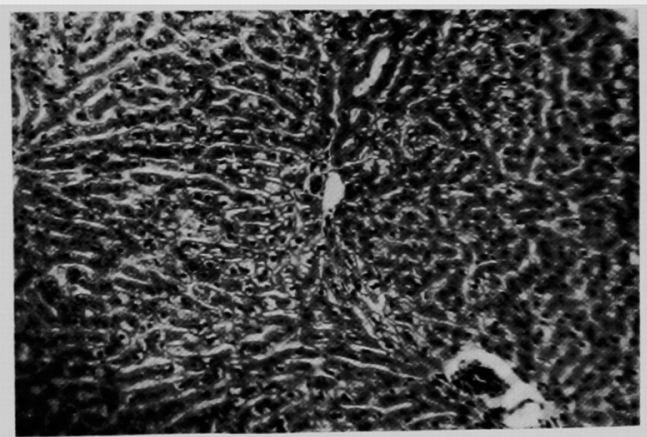

エンドリン $30 \mathrm{mg} / \mathrm{kg}$ 皮下注射家兔.

肝紐胞の著明な変性おり。

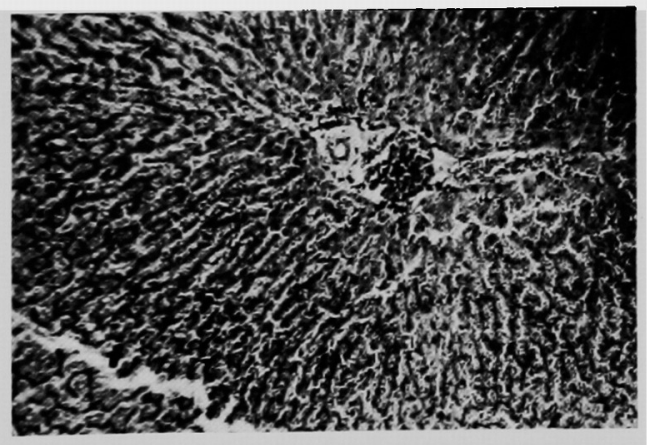

ティルドリン慢性中毒家鬼.

肺のうつ血. 著明な脂肪変性が認められる。 